\title{
Two Radio Shakespeares: Staging and Text
}

\section{Russell Jackson}

\section{(2) OpenEdition \\ Journals}

Electronic version

URL: http://journals.openedition.org/shakespeare/1281

DOI: 10.4000/shakespeare.1281

ISSN: 2271-6424

\section{Publisher}

Société Française Shakespeare

\section{Printed version}

Date of publication: 1 November 1994

Number of pages: 195-204

\section{Electronic reference}

Russell Jackson, «Two Radio Shakespeares: Staging and Text », Actes des congrès de la Société française Shakespeare [Online], 12 | 1994, Online since 01 January 2007, connection on 20 April 2019. URL : http://journals.openedition.org/shakespeare/1281; DOI : 10.4000/shakespeare.1281 
COSMOPOLITISME ET INSULARITÉ 


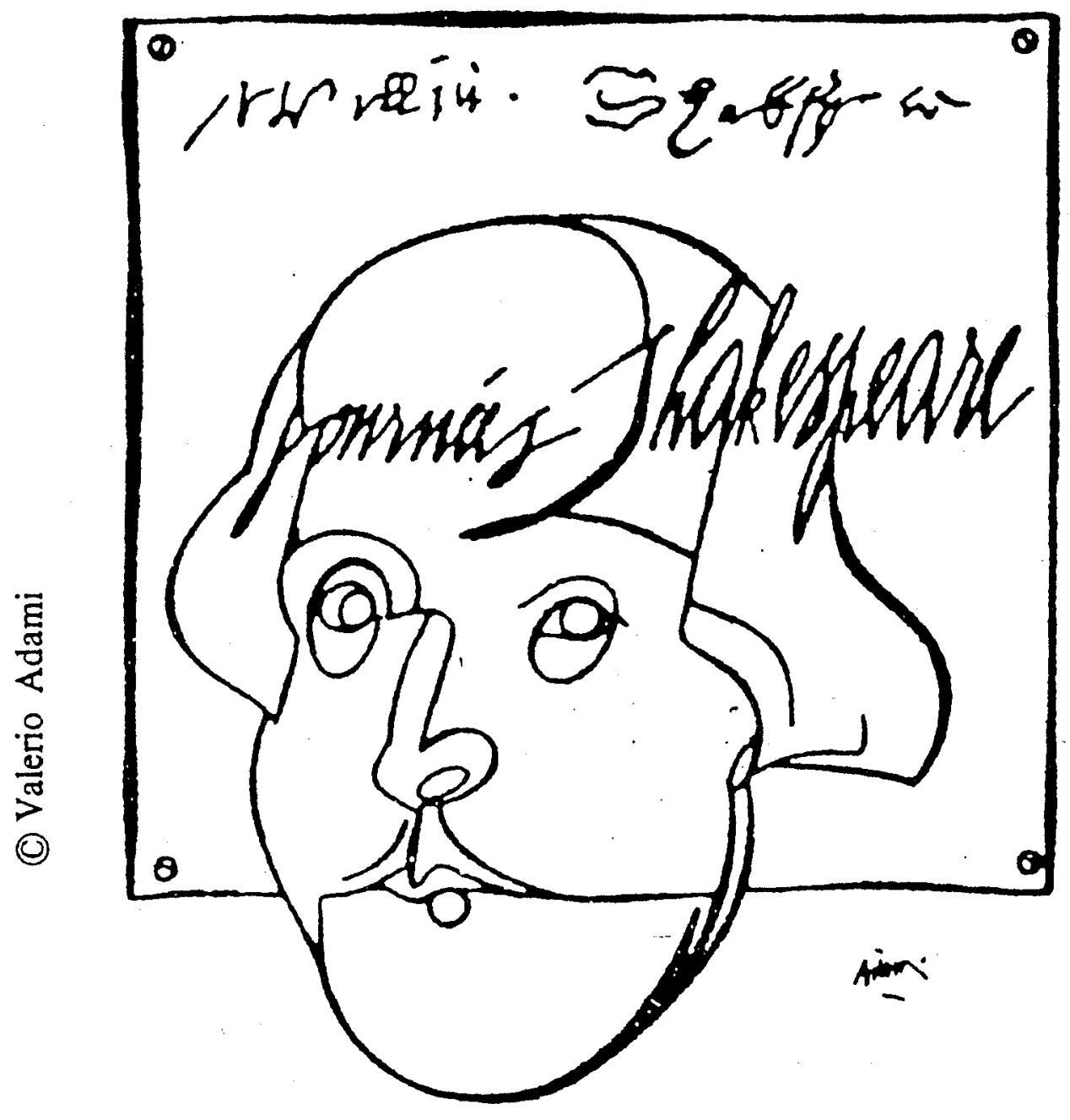

Affiche de Valerio Adami, spécialement conçue pour les journées Shakespeare 1979 


\section{SHAKESPEARE}

COSMOPOLITISME ET INSULARITÉ

Société Française Shakespeare

Actes du Congrès 1993

sous la direction

de

M. T. JONES-DAVIES

Ouvrage publié avec le soutien de

BARCLAYS

BARCLAYS BANK S.A

PARIS

LES BELLES LETTRES

1994 
Tous droits de traduction, de reproduction et d'adaptation réservés pour tous les pays.

(C) 1994 Société d'édition Les Belles Lettres, 95 bd Raspail 75006 Paris

ISBN 2.251.69122-7 


\section{Two Radio Shakespeares : staging and text}

Readers who have lost patience with the theatre - or who never had any to begin with - often argue as though the spoken text, unadulterated by any directorial intervention, would provide a full and faithful rendition of the qualities of Shakesperean drama. The notion of an uninflected but somehow expressive version of a play's text has many flaws in it, but my purpose here is not to explore them. I simply wish to mention the notion as a prelude to speaking about the performance of Shakespeare in a medium that would seem to allow exactly such an unobscured access to the "essential" play - the radio. What follows arises from my involvement as text adviser in two recent productions, both directed by Kenneth Branagh and Glyn Dearman: Hamlet and Romeo and Juliet (BBC Radio 3, 1992 and 1993 respectively) ${ }^{1}$. Radio Shakespeare is especially interesting because it focusses arguments about the performance of Shakespeare rather than somehow magically resolving them. In the case of Shakespeare on film and television, I believe that a successful version of a Shakespeare play will be one that results in a good film whose best qualities could only be achieved by having begun from the play in question. "Good" is susceptible of various - sometimes conflicting - definitions, so there will be "good" films of a given type which fail or succeed in their use of Shakespeare much as a good film of, say, Farewell My Lovely will have profited from Raymond Chandler's provision of raw material. Because Chandler is a more directive source than Shakespeare (as a novelist he prescibes atmosphere, timing, characterisation by appearance and behaviour), we can be even more confident in saying that a film of his work can be measured by its degree of success in reproducing his effects. Kurosawa's film Ran and Reinhardt and Dieterle's 1935 A Midsummer Night's Dream may be "good" films of different kinds, and I happen to think that they could only have been made with the Shakespearean material they employ, but I am not interested in awarding them points for their relative "faithfulness" to Shake- 
speare's plays. It may be less obvious, but it is no less true of radio than of film and television that there is a range of possible kinds of "good" radio.

Interpretation and mise-en-scène are essential in radio Shakespeare, even if they remain disembodied. It has been intriguing for me to move from the work on Kenneth Branagh's $M u c h$ Ado about Nothing for the cinema, where the spoken words of Shakespeare's text are to a considerable extent made redundant by the urgent need for visual images and a visual grammar of storytelling, to a Romeo and Juliet for a medium where (assuming that a "full" text is to be presented) we may even find ourselves adding to the play's words. In films of Hamlet and Romeo and Juliet directors and designers have to make fundamental decisions as to the appearance of Elsinore or Verona, and their choices result in enormous expenditures of time and money. The decisions made for a radio production are hardly momentous in terms of expense and materials, but have an impact on the finished performance that is more or less commensurate. Consider the following direction at the beginning of the second scene of Hamlet in the script for the $\mathrm{BBC} / \mathrm{Random}$ Century version :

CROSSFADE TO COURT. MURMURS AND WHISPERS IN CORNERS. GREAT DOORS OPEN. CLAUDIUS' GUARD MARCHES IN AND HALTS. THE COURT REACTS WITH CHEERS, APPLAUSE ETC. AS CLAUDIUS AND GERTRUDE ENTER AND PROCESS TO MIC[ROPHONE]. THROUGHOUT SCENE, SYCOPHANTIC REACTIONS FROM COURTIERS TO CLAUDIUS.

(Pt. I, p. 9) Juliet :

Or these two directions from the script of Romeo and

CROSSFADE MUSIC TO SQUARE IN VERONA. IN BACKGROUND SOUNDS OF BUSY LIFE, MOST PARTICULARLY FROM A TAVERN. AFTER A MOMENT THE DOOR FLIES OPEN AND SAMSON AND GREGORY BURST OUT SOMEWHAT THE WORSE FOR DRINK. THEY WEAR SWORDS AND BUCKLERS. DURING THE COURSE OF THE FOLLOWING THEY WALK. SOUNDS OF TAVERN RECEDE.

MUSIC CROSSFADES TO SMALL STREET, TALL BUILDINGS EITHER SIDE. CAPULET AND PARIS WALKING FOLLOWED BY PETER A SERVINGMAN 
The relation between such directions and the physical miseen scène of a film or stage production is indirect : they do not simply reproduce it, or provide a detailed equivalent. The Hamlet direction implies the way in which the hearer will sense Claudius' regime : oppressive, false, dangerous. It is not as concerned with visualising the scene as the two Romeo and Juliet directions, but the impression will be of space : a large slightly echoing acoustic, with an apparently dominant position of power (the microphone here being the equivalent of the dais and throne) which confers power on those who occupy it. When another, private, microphone picks up Hamlet's oppositional "aside" the pattern will be disrupted. When Gertrude tries to reason him out of his melancholy, that privacy will be shared by her, although Claudius will then seek to make the "loving and ... fair reply" public by pitching his voice away from the intimate microphone and towards the court at large. In other words, the sense of voices and sounds in space will be managed as carefully as physical positions and demeanour would be in the theatre : and a different staging for the microphone would have different results, perhaps making all Gertrude's speeches to Hamlet as public as Claudius' pronouncements and taking away a distinction between their attitudes.

In fact during the recording the physical positioning of the actors plays a part in this, but in a sometimes comically foreshortened perspective. The whispering court was achieved by having the cast stand against the walls of the studio, facing away from the microphones, and the placing of the King, Queen and Hamlet bore some resemblance to their stage positions : on the control-room monitor it looked as though Claudius' court conducted its business in a men's lavatory. The size of the room and the material it is made of can be specified on radio by the degree and quality of reverberation, but not its architectural style or decoration: a "gothic" Elsinore might be achieved by music and sound effects, much as the Ghost can be created, but Claudius' taste in interior design won't be apparent. What is most important is the sense of the relative positioning of voices, and their degree of intimacy. In this connexion, it is worth observing that Gertrude's closet can hardly have a bed in it on radio (although Juliet's bed is there, in that we hear the curtains on their rings as she closes them round her before taking the potion). Nor can a radio Hamlet be as sexually explicit in his physical treatment of Gertrude as some recent stage and television Hamlets have been. 
Polonius and Ophelia said their farewells to Laertes on the Quayside, but she did not tell her father about Hamlet's attentions until they had got into the coach that was to take them back to the castle. Later Polonius shut himself and his daughter into a small room to hear her account of Hamlet's eccentric behaviour : walls have ears in this palace.

The working out of this quasi-visual conception of the play is a major component of the radio director's work, and sometimes it results in situations that turn out to be too fussily detailed : for one scene it was originally intended that Hamlet and Polonius should walk round a fountain during a conversation, but the technical difficulties of achieving this proved disproportionate to the value of the effect. More successfully, in Romeo and Juliet the microphone swept backwards and forwards along a line of onlookers as they reacted to Romeo's furious fight with Tybalt. These are examples of effects sought in order to exploit radio's special and peculiar potential : many others are present in order to carry out by aural means on a more mundane level the text's requirements for physical action.

The directions I have quoted from the script of Romeo and Juliet are interesting because they establish mood through naturalistic devices rather than using such devices for their own sake. There is some impetus for the opening of the play's first scene if Gregory and Samson are thrown out of a tavern, and in I, 2 the echoing acoustic of the narrower street (together with perhaps a music link) gives variety to the play's settings and helps to shift to a new element of the plot. This is of course inseparable from the decisions made about what is said in each scene : Capulet's mood was reflective in his speech «But Montague is bound as well as I ...» and the quiet atmosphere suited it. In the play's first scene the expulsion of the two servants from the tavern was reinforced with a shout of "Capulet dogs" - one of the minor additions made to compensate for the lack of visible physical action - and the entrance of Tybalt marked with an additional use of his name to establish his identity (Benvolio said «Tybalt, put up thy sword» - unmetrically, but in the heat of the moment such lapses are understandable). The lines accompanying the fight as it gets worse are functional, and we felt no compunction in moving them around slightly: «Down with the Capulets» and «Down with the Montagues» (given tamely and even-handedly to "Officers" by some editors) became repeated calls, and the line «Clubs, bills and 
partisans, Strike !» was divided up. The entrance of the heads of the rival families was marked by having voices in the crowd call their names out. When Tybalt makes his entrance to seek out Romeo in III, he will be seen by a theatre audience before Benvolio says «By my head here comes the Capulets», but on radio it is useful to hear Tybalt's first line «Follow me close, for I will speak to them» before Benvolio's. In fact similar adjustments are often necessary in the theatre - for example, lines describing a character's approach before he or she speaks might have been calculated for the large open platform of the Globe rather than a modern studio stage - but radio makes more consistent use of them. Although these are mechanical and in themselves insignificant matters, they are important in ensuring that the effect on radio is of an experience wholly apprehended through the medium rather than seeming to be a fragment of some "larger" reality which is only partially and imperfectly available to the hearer. Live broadcasts of stage performances, where audible reactions can be expected from those present, make clear the completeness aimed at by drama staged expressly for radio. There are few radio experiences more frustrating than the live broadcast of a comic opera, with vague noises or silences that are followed by laughter which indicates stage-business or effects not available to the listener at home. Audible "business" is usually simple : doors, latches (each door in the studio can have a variety of locks and bolts attached to it), drink being poured, weapons clashing, and so on. Sometimes the broadcasts can aim for a subtler effect mirroring a physical move. When Romeo perceives the signs of the recent brawl «Here's much to do with hate ...» - on stage he can see blood or discarded weapons. On radio he had to walk into a sword or two lying on the ground. When Romeo jokes about the plantain leaf being good for a bruised shin we need to hear that he has kicked Benvolio (but without any line to register it - «why dost thou kick my leg ?» would sound odd - Benvolio's tone has to carry the message). More subtly, when Juliet, anxious to hear the Nurse's news, is rubbing her aching back, we need a little more than the Nurse's spoken lines to convey the effect of the massage. Juliet, having returned from Laurence with the potion, prostrates herself before her father - in the radio production the direction of her voice should indicate this. The Apothecary lets his feelings about Romeo's little sermon on gold and poison be known with a «Bah !» that might be too eloquent in the theatre. 
A list of the minor adjustments made to the text in either play would show that they often serve to make up for the absence of a visual signal that a character has responded to a speech (it is expedient to have servants acknowledge a summons or command with «sir» or «madam»). In one case, in the final scene of Hamlet, Gertrude was given one word ("Hamlet") to establish her proximity to her son at a vital moment. Sometimes the cue for a line might be silent on stage, but vocalised on radio : the reaction to Hamlet's "Man delights not me» implied by the next line is "smiling", but we need to perceive an audible smirk. Sometimes an attitude can be conveyed in such a way - as when we hear the First Player join in on the final line of Pyrrhus' speech as delivered by Hamlet, suggesting engagement, enjoyment, a sense of the moment as "performance". Not all gestures can be replicated in this way: an extra word or two will indicate that Osric is doffing or donning his hat, but no radio sound can be devised that will show Polonius touching his head and his shoulders when he says «Take this from this if this be otherwise». A rewrite of the line was considered - but not for long. It was simpler just to accept that a point had been lost.

Work of this kind is a salutary reminder of a specifically dramatic dimension of the play texts : the shaping and direction of scenes and the maintaining of a proper forward momentum is essential. The story of each sequence has to be told clearly and with appropriate urgency, vocal and physical characterisation have to be precise and subtle. In a scene with long speeches the presence of the actors responding but not speaking is vital to an audience's sense of the speeches having an effect. To speak Friar Laurence's admonishment of Romeo eloquently is not enough in itself : we need a sense that the Friar is responding to Romeo's mood, that he has a reason for saying what he does in the order in which it is uttered, and that he does not know quite how his speech is to continue or conclude. This does not simply mean that the actor playing Romeo must make some kind of noise during the speech at appropriate moments, but that the actors work together with an imaginative sense of the effect on each other of what they say. The sense of the words as performative, and of dialogue as interactive is vital. "Asides" register very directly in radio through the positioning of actors, and the medium is capable of greater complexity in levels of consciousness than any of the Shakespeare texts demand : the recent BBC adaptation of Zola's $L a$ 
Bête Humaine was a notable example of interior monologue and shifts from one character's perception of events to another's. Thoughts that develop into soliloquies are more easily accommodated on radio than in conventionally realistic film technique, which can make looks eloquent but is embarrassed by verbalised reflection. In other words, although radio plays are recorded without scenery or costumes and in even lighting, with the actors speaking to microphones and in front of a control room window, their imagination must be as active as that of the actor in his stage performance or the listening audience. In fact, the studios at BBC Maida Vale used for Hamlet and Romeo and Juliet ( 7 and 6 respectively) allow not just the listener but the actor as well to have a sense of movement from room to room, and of different kinds of space.

Studio Six at Maida Vale is a state-of-the-art drama studio, and seems something like a mock-up of a house at an Ideal Home exhibition, with a staircase, a hallway, a room with paving-stones on the floor, a winding corridor leading to an acoustically "dead" area, movable panels in the walls to give absorbent or reflective qualities, and even a "domestic" area with kitchen appliances. For the first and second "balcony" scenes in Romeo it was possible to use an upper window looking down onto the paved "courtyard" which served as the orchard (rustling undergrowth underfoot created with the help of bits of old tape !) and to lower the lighting so that the actors were working in a less antiseptic atmosphere than the studio usually affords. There are movable screens that can be drawn round a part of the studio space to create an enclosed area (the Friar's cell, Juliet's bedroom). A section of the floor with gravel for outside footsteps, a flight of stairs with three parallel kinds of tread (carpet, wood, stone) and even a pair of French windows. It is very like being in a theatre company's rehearsal room mock-up of a set that the cast has yet to walk on. There are even "practice skirts" in a variety of materials to provide the sound of the character's clothes - like those worn in a theatrical rehearsal to give actors the sense of the skirts or cloaks they will wear "on the night". The actor is in an environment that in many ways is conducive to imagining the circumstances of the play. On the other hand, radio acting requires concentration that will set aside the mechanics of production - much as a film actor needs to sustain a role through the discontinuous process of filming and through repeated takes separated by long waits. And there is no au- 
dience, only the faces behind the control-room window (when it is visible) and the disembodied voice of the director on the talk-back. Sometimes the discontinuity is as severe as those legendary film situations where one side of a conversation was filmed by one of the actors in the absence of the interlocutor. In these two plays, for example, the Ghost of Hamlet's father was recorded separately from the scenes in which he appeared, and played back to the actors on the battlements or in Gertrude's room ; and the fights were recorded separately and played back in a similar way to the actors to respond to. In two instances the off-stage voices of the Nurse and Capulet's wife were treated in the same way. Even when this is not the case, as in a film, it is rare for a play to be recorded in its own running order : the difficulties of scheduling involve juggling with the availability of a large cast.

Both the productions I have been talking about were unusual in two respects. They both present a "full" version of the play, and they have casts that are distinguished beyond the aspirations of most theatre directors. The "fullness" of a Shakespearean text is, of course, a debatable issue. In Hamlet we used all the available material, from the 1623 Folio and the Second Quarto, which results in a text probably never heard in the author's lifetime (and perhaps never envisaged by him). The possibility of recording everything seemed too good to miss, so the elaboration of Rosencrantz and Guildenstern's news about the boy players is there, as well as various other less obscure passages not often played. If we had elected to perform the Folio text as a "performance version" we would have omitted, among other passages, «How all occasions ...», which would have resulted in our offering a "full" text that contained less than many others. As far as the buying public is concerned there are full texts or cut texts : it would have been nice to have done a version on $C D$ that would enable scholars to mix and match! The choice of readings was based on that of the Oxford editor, G. R. Hibbard, with some adjustments from other editions according to the predilections of the cast or the production team. To take two examples, Judi Dench wanted "nighted" rather than "nightly" for Hamlet's mantle and in Romeo and Juliet Sir John Gielgud balked in the readthrough at one word, but gracefully accepted our decision when it came to recording (explaining that he was accustomed to the other reading «In his experience of the play» but had not wished to show any unmannerly recalcitrance). The text adviser's role in this is to par- 
ticipate in discussions rather than present the "truth", much as in another dimension of the job, working on the text with actors, the task is helping open up the interpretative possibilities of the lines rather than offering some undeniably "accurate" reading or inflection. It has to be said that in radio there is much less time for "finding" a reading than in the theatre or cinema : a few seconds of quick debate in the control room often result in a dash round to the studio by the director to suggest a line reading to an actor - of the kind that they might expect to arrive at after a longer and more experimental process in theatre rehearsals. In this respect, radio work cuts corners - or at least takes them at speed.

The "eminence" of the cast, and their familiarity with the plays (sometimes in many productions over decades) has not in my experience resulted in their presenting the director with a settled performance of their individual roles, or an inflexible confidence in a particular reading of their lines. Rather, the process has been one of actors playing off each other, finding new nuances in parts they have already played. It has not seemed (to take the most obvious example) as though Sir John Gielgud has come in to give us "his" ghost or Friar Laurence - in the case of the latter especially, the performance has responded to the new circumstances and the pressure of working with new actors and a new director. In the case of the Romeo and Juliet, Kenneth Branagh and Samantha Bond, the performers had played the roles together six years before, but it was clear to me, having worked on that production in the same capacity, that the performances for the radio production were markedly different in details and overall shape. Most of the actors in both productions have worked together before, often as part of the rolling quasi-repertory company that Renaissance has assembled over the past few years in films and theatre. Judi Dench had performed Gertrude (at the National Theatre) but not the Nurse ; Derek Jacobi is unlikely to be cast as Mercutio in a stage production (he is too mature for most casting policies, and perhaps too expensive to be wasted on a character who dies half way through the evening). He has played most of the male roles in the play and directed Kenneth Branagh in it in 1988, but as Claudius in Hamlet he was able to play a role he has not yet tackled on stage.

The production of Shakespeare on the radio is dominated by work on the text, by the actors themselves and by the director. The director's staging of the play for radio, however, is of great impor- 
tance, creating the listeners' sense of the surroundings in which the action takes place, and the effect on one another of the character's behaviour. "Atmosphere", conveyed by music and sound effects (whether added afterwards or performed on the spot) has to be carefully judged. But the dominant interpretative effect achieved in the theatre by stage design, costume and the stage business is absent : the words carry more weight. If the listener is to hear more than a recital of the words, however, it is vitally important that the director, the actors and the production team have a sense of the play's scenes as a series of transactions, in which the language has a performative effect, and that they share a vision of Elsinore or Verona. Radio offers no real escape from staging the play.

Russell JACKSON

The Shakespeare Institute, University of Birmingham

\section{NOTE}

1. The two recordings, produced by BBC Radio 3 in collaboration with the Renaissance Theatre Company and Random Century Audiobooks, are available in Great Britain on disc and audiocassette. For a useful introduction to radio drama, see Peter Lewis, ed., Radio Drama (London, 1981), especially the articles by John Tydeman ("The Producer and Radio Drama : a Personal View") and John Drakakis ("The Essence that's not Seen : Radio Adaptations of Stage Plays"). Tydeman has produced many of Shakespeare's plays during his long career in radio ; Drakakis' article is a stimulating and well-informed study of the theoretical as well as practical issues involved. 